\title{
Sustentabilidade urbana
}

E

STUDOS AVANÇADOS, em seu número 97, publica contribuições de pesquisadores que participam do Projeto USP Cidades Globais. ${ }^{1}$ São tratados temas de destacada relevância e importância estratégica para o planejamento futuro da sustentabilidade urbana. Compreendem questões conceituais, metodológicas e resultados de investigações relacionadas aos padrões urbano-demográficos, aos indicadores de desigualdades, aos instrumentos legais de sustentabilidade, à configuração de novo ecossistema em torno das florestas urbanas, aos desafios mais propriamente pertinentes ao planejamento estratégico, à inovação tecnológica e aos recursos humanos. No conjunto, a leitura dos artigos permite avaliar os compromissos da USP com a formulação de políticas voltadas para a melhoria da qualidade de vida urbana.

A proposta de um dossiê sobre Escravidão nasceu dos debates contemporâneos a respeito das formas recentes centradas em torno do tráfico e escravidão de seres humanos. A escravidão desde a Idade Moderna tem mobilizado a atenção acadêmica em torno da natureza dessa modalidade de opressão, de questões metodológicas e de seu alcance e extensão geográfica, ao lado do interesse em demarcar diferenças entre a escravidão no Mediterrâneo e no Atlântico. Nesse domínio, o dossiê focaliza esse fenômeno nas doutrinas teológicas, no direito canônico, bem como no universo de pregações e devoções que circularam na América colonial portuguesa, revelando como operavam os conceitos de escravidão e liberdade nos sermões brasileiros e como representavam a presença de negros e indígenas na população.

Como de hábito, a seção de Literatura comparece enriquecida. O espaço doméstico, mais propriamente a casa e a morada, é objeto de estudo em três romances brasileiros: Fogo morto, A menina morta e Crônica da casa assassinada. Outras contribuições tratam de Drummond e a ditadura militar, da representação da cortesã em conto de Machado de Assis, do relato pessoal de eventos traumáticos no qual a escrita se converte em cena substitutiva da pólis, e da presença da literatura em O capital de Karl Marx.

Aseção de Atualidades aborda três questões de nossa contemporaneidade: $\mathrm{o}$ direito humano à alimentação, $\mathrm{o}$ ato infracional na adolescência e o cyberbullying.

Nota

l Para mais informações, consultar: <http://www.iea.usp.br/pesquisa/projetos-institucionais/usp-cidades-globais>.

Sergio Adorno ${ }^{\mathrm{I}}$

${ }^{\text {I }}$ Faculdade de Filosofia, Letras e Ciências Humanas, Universidade de São Paulo, São Paulo, Brasil. @-sadorno@usp.br / https://orcid.org/0000-0002-5358-1289 